\title{
Quality of Work Life and Psychological Empowerment among Employees: Malaysian Government-Linked Company
}

\author{
Nurul Isnaini Ahmad Sharani, Shah Rollah Abdul Wahab, Umar Haiyat Abdul Kohar, Nurul \\ Farhana Mohd Noordin, Wan Mohd Azam Wan Mohd Yunus
}

\begin{abstract}
Psychological empowerment may provide more satisfaction towards $a$ job and better productivity towards employees' work and life. The aim of this study is to investigate the link between psychological empowerment and the quality of work life [QWL] in a government-linked company in Malaysia. Employing a cross-sectional survey research design, 182 employees from a financial sector company were recruited using simple random sampling method. The Psychological Empowerment Questionnaire [Spreitzer, 1995] and Quality of Work Life Questionnaire [Walton, 1980] were used to measure psychological empowerment and the quality of work life [QWL]. Data was analyzed using Statistical Package for Social Science [SPSS]. Results showed that, the overall level of psychological empowerment is at a high level, while the level of quality of work life $[Q W L]$ is at a moderate level. The findings also showed that the relationship between psychological empowerment and the quality of work life has a very weak relationship. It can be concluded that, psychological empowerment is associated to quality of work life among the employees in a Malaysian government-linked company
\end{abstract}

Keywords : cross-sectional, government-linked company, psychological empowerment, quality of work life.

\section{INTRODUCTION}

There is increasing trend of turnover intention especially among younger generation of employees [1]. Quality of Work Life $[\mathrm{QWL}]$ is viewed as an important part for an organization to attract and maintain potential employees in order to remain in this competitive world [2]. Walton [3] highlighted quality of work life as a culture that creates a high level of commitment among colleagues in an organization. High quality of work life is essential for an organization in order to

Revised Manuscript Received on October15, 2019

* Correspondence Author

Nurul Isnaini Ahmad Sharani, School of Human Resource Development \& Psychology, Universiti Teknologi Malaysia, Johor, Malaysia. Email: nurulisnaini94@gmail.com.

Shah Rollah Abdul Wahab, School of Human Resource Development \& Psychology, Universiti Teknologi Malaysia, Johor, Malaysia. Email: shah@management.utm.my

Umar Haiyat Abdul Kohar, Azman Hashim International Business School, Universiti Teknologi Malaysia, Johor, Malaysia. Email: wmohdazam@utm.my. Email: umarhaiyat@utm.my

Nurul Farhana Mohd Noordin, School of Human Resource Development \& Psychology, Universiti Teknologi Malaysia, Johor, Malaysia. Email: nfarhana@utm.my.

Wan Mohd Azam Wan Mohd Yunus*, School of Human Resource Development \& Psychology, Universiti Teknologi Malaysia, Johor, Malaysia. Email: wmohdazam@utm.my. retain and attract employees to stick with the organization [4]. By improving the quality of work life among employees, employees' productivity can be increased and higher probability for the employees to work in an effective way to achieve their goals. Furthermore, having quality of work life will lead to better well-being of the workers and society [5] Those who are enjoying their jobs are said to have high quality of work life rather than those who are unhappy with their jobs [6]. In Malaysian context, one study showed that public sector employees demonstrated a higher satisfactory level of quality of work life compared to private sector employees [7]. On the other hand, empowerment is one of the strategies that had been widely used by the organizations in the public and private sectors to improve their employee's performance towards achieving the organization's goals and good quality of work life. In line with this, theorists also explained that empowerment is an emerging construct used for organizational effectiveness [8]. Empowering employees is also an innovative way to redesigning work process and correcting errors in production and service area [8]. Psychological empowerment had evolved over time through the work of a number of researchers [10-12]. Psychological empowerment will provide increasing satisfaction towards job and better productivity in the employees' work life. Many studies have indicated that an empowering work environment can improve employee outcomes such as satisfaction, work engagement and performance [13,14].

There are many research that had been conducted on psychological empowerment and quality of work life [QWL] that are related to organizational commitment [15], employee engagement [16], turnover intentions and job satisfaction [17-19]. Despite this, limited research that had been conducted which focused specifically on the psychological empowerment and the quality of work life in a specific category of organization - the government-linked companies. Therefore this study builds on earlier works by investigating a different variable that might be important to this specific category of organization. Furthermore, past research on psychological empowerment and the quality of work life usually been conducted in other Asian and Middle East countries such as in India [20,21], Indonesia [22] and also Iran $[23,24]$. But to the knowledge of the authors, research on psychological empowerment and quality of work life in Malaysian context is scarce. Malaysia is a multiracial country with different races, cultures and beliefs that are being practiced by the citizens in Malaysia.

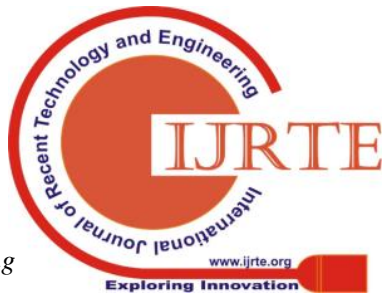


Quality of Work Life and Psychological Empowerment among Employees: Malaysian Government-Linked

Company

These differences among the employees can give an impact towards how the employees perceived their job based on the environment of workplace and engagement with their colleagues. It is also argued that the way people belief and value their works will change their behavioral outcomes [10]. This means that the beliefs of the employees will show how they behave to empower themselves and having a good quality of work life.

Other than that, many of the previous studies that had been found related to psychological empowerment and quality of work life is being conducted in the settings of services and trade sector, education and healthcare sector which are mostly related to the middle-level executives, teachers and the nurses. However, there is only one study that is been conducted among the employees in a financial sector which towards the bankers in Indonesia [22]. Therefore, there is a need to conduct this study among the employees in the financial sector because of the nature of work and more workload were found to be causes of stress among employees in the financial sector of Malaysia [25]. Therefore, the main aim of this study is to examine the link between psychological empowerment and quality of work life in a government-linked company focusing on the financial sector which related to the employees in an investment field.

\section{MATERIALS AND METHODS}

This descriptive study is cross-sectional in nature. The population of the study consists of 367 employees who are working in a government-linked company in Malaysia. Therefore, the sample size should be at least 186 [26]. This study employs simple random sampling method to distribute the questionnaires in which 182 respondents returned the completed questionnaires. Psychological empowerment was assessed using a The Psychologival Empowerment Instrument by Spreitzer [11] while quality of work life was assessed using The Quality of Work Life [QWL] questionnaire by Walton [3]. The Statistical Packages for Social Science [SPSS] was used to analysed the data. Descriptive analysis was used to identify the demographics information, level of psychological empowerment and level of quality of work life. Moreover, Spearman correlation was used to investigate the relationship between psychological empowerment and level of quality of work life.

\section{RESULTS}

Table I below demonstrated the findings from data collection for the demographics section.

Table I: Demographics Information

\begin{tabular}{|c|c|c|c|}
\hline \multicolumn{2}{|c|}{ Demographics Information $[n=182]$} & $\begin{array}{c}\text { Frequency } \\
{[f]}\end{array}$ & $\begin{array}{c}\text { Percentage } \\
{[\%]}\end{array}$ \\
\hline \multirow{2}{*}{ Gender } & Male & 84 & 46.2 \\
\hline & Female & 98 & 53.8 \\
\hline \multirow{4}{*}{ Age Range } & 20 to 30 years & 37 & 20.3 \\
\hline & 31 to 40 years & 48 & 26.4 \\
\hline & 41 to 50 Years & 72 & 39.6 \\
\hline & 51 to 60 Years & 25 & 13.7 \\
\hline \multirow{3}{*}{ Ethnicity } & Malay & 113 & 62.1 \\
\hline & Chinese & 37 & 20.3 \\
\hline & Indian & 32 & 17.6 \\
\hline \multirow{3}{*}{$\begin{array}{c}\text { Work } \\
\text { Experiences }\end{array}$} & 0 to 1 Year & 11 & 6.0 \\
\hline & 2 to 5 Years & 44 & 24.2 \\
\hline & 6 to 10 Years & 34 & 18.7 \\
\hline
\end{tabular}

\begin{tabular}{|c|l|c|c|}
\hline & More than 10 Years & 93 & 51.1 \\
\hline \multirow{4}{*}{$\begin{array}{c}\text { Income } \\
\text { Level }\end{array}$} & RM2000 to RM3000 & 12 & 6.6 \\
\cline { 2 - 4 } & RM3001 to RM4000 & 56 & 30.8 \\
\cline { 2 - 4 } & RM4001 to RM5000 & 50 & 27.5 \\
\cline { 2 - 4 } & RM5001 and above above & 64 & 35.2 \\
\hline \multicolumn{2}{|c|}{ Total } & 182 & 100 \\
\hline
\end{tabular}

The level of psychological empowerment, quality of work life and the relationship between psychological empowerment and quality of work life are shown in Table 2. Overall, the respondents were reported to experience high level of psychological empowerment [3.83 \pm 0.37$]$ and possesses moderate level of quality of work life [3.49 \pm 0.39$]$. In terms of the link between psychological empowerment and quality of work life, a significant and weak positive relationship was recorded [ $r=0.25, p<0.002]$. In other words, employees who experience moderate level of psychological empowerment are linked with moderate level of quality of work life.

\section{Table II: Psychological empowerment and quality of work life among employees}

\begin{tabular}{|l|c|c|c|}
\hline Variables and dimensions & $\boldsymbol{M}$ & $\boldsymbol{S D}$ & Level \\
\hline Psychological empowerment & $\mathbf{3 . 8 4}$ & $\mathbf{0 . 3 7}$ & High \\
\hline Meaning & 4.13 & 0.55 & High \\
\hline Competence & 4.11 & 0.48 & High \\
\hline Self-Determination & 3.86 & 0.56 & High \\
\hline Impact & 3.29 & 0.64 & Moderate \\
\hline Quality of work life & $\mathbf{3 . 4 9}$ & $\mathbf{0 . 3 9}$ & $\begin{array}{c}\text { Moderat } \\
\mathbf{e}\end{array}$ \\
\hline Adequate and fair compensation & 3.50 & 0.64 & Moderate \\
\hline Safe and healthy working condition & 3.82 & 0.80 & High \\
\hline $\begin{array}{l}\text { Opportunity for using and developing } \\
\text { human capacity }\end{array}$ & 3.49 & 0.54 & Moderate \\
\hline $\begin{array}{l}\text { Opportunity for continue growth and } \\
\text { security }\end{array}$ & 3.39 & 0.58 & Moderate \\
\hline $\begin{array}{l}\text { Social integration in the work } \\
\text { organization }\end{array}$ & 3.37 & 0.53 & Moderate \\
\hline Employment right & 3.31 & 0.60 & Moderate \\
\hline $\begin{array}{l}\text { The effect of job demand on personal } \\
\text { lives }\end{array}$ & 3.32 & 0.71 & Moderate \\
\hline Social relevance of work life & 3.75 & 0.63 & High \\
\hline \begin{tabular}{l} 
Psychological Empowerment*Quality of work life [r $=0.25 * *$ \\
\hline Note: $* * * p<0.001 ; n=182$
\end{tabular} & & \\
\hline
\end{tabular}

\section{DISCUSSION}

Based on the findings, there are three dimensions that show a high level of psychological empowerment which are the meaning, self-determination and competence. While the impact dimension scored a moderate level result. The highest mean score among the four dimensions was shown by the meaning dimension. This showed that the employees in this company having their own internal drive or motivation in doing their work. Besides that, the employees also feel that their job is very important to them. This findings are in line with a previous study [22] that found there are three dimensions which are meaning, competence, and impact were perceived as good [mean between 3.41 to 4.20]. While, indicator of self-determination is perceived very good [on average between 4.21 to 5]. In contrast, another study found high level of competence and meaning only while the self-determination and impact score were at the moderate level [8]. 
This research shows that the there are two dimensions which showed a high level of quality of work life [QWL]. The dimensions are safe and healthy working condition and social relevance of work life. While the other six dimensions which are adequate and fair compensation, opportunity for using and developing human capacity, opportunity for continue growth and security, social integration in the work organization, employment right and the effect of job demand on personal lives were at the moderate level. This findings are consistent with most of the result from a study which also found the overall dimensions of quality of work life shows an average level for each dimensions [27]. The most important factors that influence the quality of work life is an adequate and fair compensation and safe and healthy working condition [27]. In this study the safe and healthy working condition shows a high level which indicated that a comfortable working environment is needed by the employees in order to have a good quality of work life. The work done by the employees also is important for the community which make them appreciate the value of their work.

There was a very low positive relationship between the psychological empowerment and the quality of work life among the employees in this company. This result is in line with the previous studies $[21,22]$. The result shows that the psychological empowerment is positively correlated to the quality of work life. Besides that, one of these previous study also shows that overall psychological empowerment dimensions are significantly related to quality of work life [21]. Based on this result, it shows that psychological empowerment directly influence the quality of work life. Higher psychological empowerment will give a good quality of work life among the employees.

\section{CONCLUSION}

As a conclusion, this study argued that psychological empowerment and the quality of work life [QWL] are interrelated to each other, particularly in this financial company of a government-linked organization in Malaysia. Employees who have great motivation in themselves are associated with having good quality of work life [QWL]. Psychological empowerment and the quality of work life are important for our life because it balances ourselves and the environment surrounds us. It is hoped that this study will give benefits to the employees and also the organizations in order to have a great quality of work life.

\section{REFERENCES}

1. Aziz, K. A., Rahman, R. H. A., Yusof, H. M., \& Yunus, W. M. A. W. M A Review on Generational Differences and Work-related Attitude. International Journal of Academic Research in Business and Social Sciences 2018; 8(8), 346-360.

2. Siron R, Tasripan MAH, Majid MY, "A study of quality of working life amongst managers in Malaysian industrial companies," J. of Business and Economics, vol. 4, 2013. pp. 561-570

3. Walton R., "Quality of work life activities: A research agenda," Prof Psychol, vol. 11, pp. 484-93.

4. Nanjundeswaraswamy TS, Swamy DR, "Review of Literature on Quality of Work life,” Int J Qual Res., vol. 7, 2013, pp. 201-14.

5. Noor SM, Abdullah MA, "Quality work life among factory workers in Malaysia,” Procedia-Social Behav Sci., vol. 35, 2012, pp. 739-745.

6. Balaji R, "A Study on Quality of Work Life among Employees," Int J Innov Res Sci Eng Technol., vol. 2, 2014, pp. 470-472

7. Permarupan PY, Al-Mamun A, Saufi RA, "Quality of work life on employees job involvement and affective commitment between the public and private sector in Malaysia," Asian Soc Sci., vol. 9, 2013 pp. 268-278.

8. Chiang C-F, Jang S, "The antecedents and consequences of psychological empowerment: the case of Taiwan's hotel companies,". $J$ Hosp Tour Res., vol. 32, 2008, pp. 40-61.

9. Degago E, "A Study on Impact of Psychological Empowerment on Employee Performance in Small and Medium Scale Enterprise Sectors,' Eur J Bus Manag., vol. 27, 2014, pp. 60-72.

10. Conger JA, Kanungo RN, "The empowerment process: Integrating theory and practice," Acad Manag Rev.,vol. 13, 1988 pp. 471-482.

11. Spreitzer GM, "Psychological empowerment in the workplace: Dimensions, measurement, and validation," Acad Manag J., vol 38, 1995, pp. 1442-1465.

12. Thomas KW, Velthouse BA, "Cognitive elements of empowerment: An "interpretive" model of intrinsic task motivation," Acad Manag Rev. vol. 15,1990 , pp. 666-681.

13. Kok PC, "A study of the impact of the empowerment on employee performance in the automative industry in Malaysia," Open University Malaysia, 2011.

14. Wang G, Lee PD, "Psychological empowerment and job satisfaction: An analysis of interactive effects," Gr Organ Manag. Vol. 34, 2009, pp. 271-296

15. Parvar MRF, Allameh SM, Ansari R, "Effect of quality of work life on organizational commitment by SEM [case study: OICO company]," Int J Acad Res Bus Soc Sci. vol. 3, 2013, pp. 135

16. Stander MW, Rothmann S, "Psychological empowerment, job insecurity and employee engagement," SA J Ind Psychol. Vol. 36, 2010, pp. $1-8$.

17. Saif NI, Saleh AS, "Psychological Empowerment and Job Satisfaction in Jordan Hospitals," Int J Humanit Soc Sci. vol. 2013, pp. 250-257

18. Nel T, Stander MW, Latif J, "Investigating positive leadership, psychological empowerment, work engagement and satisfaction with life in a chemical industry," SA J Ind Psychol. vol. 41, 2015, pp. 1-13.

19. Indradevi R, "The impact of psychological empowerment on job performance and job satisfaction in Indian software companies," Int J Multidiscip Manag Stud. vol. 2, 2012, pp. 36-48.

20. Nayak T, Sahoo CK, Mohanty PK, "Quality of work life plays the mediating role in between workplace empowerment and employee commitment: a study on healthcare employees of an Indian State," 2015

21. Srivastava S, Pathak D, "Investigating the mediating effect of psychological empowerment on quality of work life-organisational commitment relationship: a study on Indian IT sector managers," Int J Manag Dev. vol. 1, 2016, pp. 196-214

22. Hermawati A, Suci RP, "Pendekatan Psychological Empowerment Berbasis Quality Of Work Life Sebagai Upaya Optimalisasi Kinerja Karyawan Bank Syariah Di Jawa Timur," Prosiding Seminar Nasional, Fakultas Ekonomika dan Bisnis, Universitas Semarang, 2015

23. Salimi S, Saeidian N, "Relationship between quality of work life and psychological empowerment by employees' productivity [structural equations modeling]," Int J Educ Psychol Res. vol. 1, 2015, pp. 10

24. Kermanshahi MM, Hozhabrnejad N, "The Impact of quality of work life and organizational health on teacher empowerment," Int J Res Organ Behav Hum Resour Manag. vol. 4, 2016, pp. 44-51

25. Teck-Hong T, Ismail MI, "Identifying Work-Related Stress among Employees in the Malaysian Financial Sector," World J Manag., vol. 3, 2011, pp. 229-243.

26. Krejcie R V, Morgan DW, "Determining sample size for research activities," Educ Psychol Meas. vol. 30, 1970, pp. 607-610.

27. Ashwini J, Anand D, Ghura AS, Mathew J, Wahdan H, Nandkumar AS, "Quality of work life evaluation among service sector employees," J Bus Manag. vol. 16, 2014, pp. 1-12

\section{AUTHORS PROFILE}

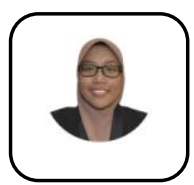

Nurul Isnaini Ahmad Sharani was an undergraduate student for Bachelor of Psychology with Human Resource Development at the School of Human Resource Development \& Psychology, Faculty of Social Sciences and Humanities, Universiti Technology Malaysia.

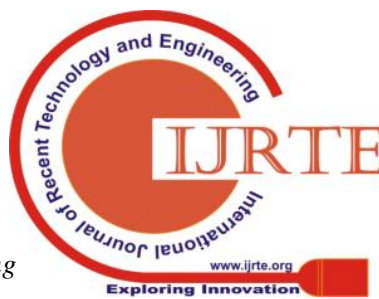




\section{Company}

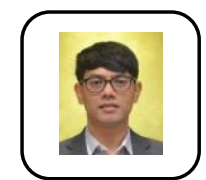

Shah Rollah Abdul Wahab is a senior lecturer at the School of Human Resource Develeopment \& Psychology, Universiti Technology Malaysia. He obtained his Ph.D in Management from Universiti Technologi Malaysia. He is with UTM for more than 17 years and currently active in research related to Safety Management, Transformational Leadership and Employee Training

Umar Haiyat Abdul Kohar is a senior lecturer at the Azman Hashim International Business School, Johor Bahru Campus, Universiti Teknologi Malaysia. He completed his bachelor's and master's degrees from Universiti Teknologi MARA (UiTM) Shah Alam and a $\mathrm{Ph} . \mathrm{D}$. degree from RMIT University, Australia. His research interests are in the area of entrepreneurship, innovation management, and education.

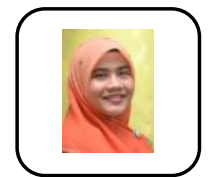

psychology.



Wan Mohd Azam Wan Mohd Yunus is a senior lecturer in psychology at the School of Human Resource Development \& Psychology, Faculty of Social Sciences and Humanities, Universiti Technology Malaysia. He obtained his Ph.D in Clinical Psychology at King's College London, UK and M.Clin.Psych at Universiti Kebangsaan Malaysia. He is currently active in research related to digital mental health, clinical psychology and abnormal psychology. 